\title{
0425 Efficacy and safety of maraviroc in treatment-experienced (TE) patients infected with R5 HIV-I : 96-week combined analysis of the MOTIVATE I and 2 studies
}

\author{
WD Hardy*1, R Gulick², HB Mayer³ , G Fätkenheuer ${ }^{4}$, M Nelson5, J Heera ${ }^{3}$, \\ N Rajicic ${ }^{6}$ and J Goodrich ${ }^{3}$
}

Address: ${ }^{1}$ Cedars-Sinai Medical Center/Geffen School of Medicine, UCLA, Los Angles, CA, USA, ${ }^{2}$ Weill Medical College of Cornell University, Internal Medicine, New York, USA, ${ }^{3}$ Pfizer Global Research and Development, New London, CT, USA, ${ }^{4}$ University of Cologne, Köln, Germany, ${ }^{5}$ Chelsea \& Westminster Hospital, London, UK and ${ }^{6}$ Pfizer Global Research and Development, New York, NY, USA

* Corresponding author

from Ninth International Congress on Drug Therapy in HIV Infection

Glasgow, UK. 9-13 November 2008

Published: 10 November 2008

Journal of the International AIDS Society 2008, I I (SuppI I):O47 doi:I0.II86/I758-2652-II-SI-O47

This abstract is available from: http://www.jiasociety.org/content/I I/SI/O47

(C) 2008 Hardy et al; licensee BioMed Central Ltd.

\section{Purpose of the study}

MOTIVATE 1 and 2 are randomized, double-blind, placebo (PBO)-controlled Phase III studies assessing the efficacy and safety of maraviroc (MVC) in TE patients with R5 HIV-1. In both studies, MVC (QD/BID) + optimized background therapy (OBT) demonstrated significantly greater virological and immunological efficacy and a similar safety profile compared with $\mathrm{PBO}+\mathrm{OBT}$ at weeks 24 and 48 [1].

\section{Methods}

1,076 patients with triple drug-class experience and/or triple-class resistance, R5 virus (Trofile ${ }^{\mathrm{TM}}$ ), and HIV-1 RNA $\geq 5,000$ copies/mL were randomized 1:2:2 to PBO, MVC QD or BID. All patients received OBT (3-6 antiretrovirals +/- low-dose ritonavir; darunavir/r not permitted due lack of PK data). The study was unblinded after week 48 (primary end-point). Patients in both MVC arms who had not experienced treatment failure through week 48 were rolled over to open-label MVC BID, but are referred to below by their baseline (BL) randomization assignment. The PBO arm contains patients who were virologically suppressed at week 48 and remained on OBT through week 96. After week 48, substitutions in OBT were allowed in all arms.

\section{Summary of results}

More patients in the MVC arms maintained HIV-1 suppression (to $<400$ and $<50$ copies $/ \mathrm{mL}$ ) through week 96 than those in the PBO arm. Fewer patients in the MVC arms experienced virologic failure between week 48 and 96 compared with the PBO arm. Incidence of SAEs, Category $\mathrm{C}$ events and malignancies were similar among treatment arms even when unadjusted for exposure, which was significantly greater in each of the MVC arms compared with the PBO arm. See table in Figure 1.

\section{Conclusion}

MVC+OBT resulted in durable viral suppression through week 96 in these TE patients with R5 HIV-1. Pooled analyses revealed no new or unique safety signals between 48 and 96 weeks. Serious adverse events, Category C events and malignancies occurred with similar frequency among treatment groups. 


\begin{tabular}{|c|c|c|c|}
\hline $\begin{array}{l}\text { Baseline randomization assignment } \\
\text { (includes all patients who received at } \\
\text { least one dose of study treatment) }\end{array}$ & $\begin{array}{l}\mathrm{PBO}+\mathrm{OBT} \\
\mathrm{N}=\mathbf{2 0 9}\end{array}$ & $\begin{array}{l}\text { MVC QD + } \\
\text { OBT } \\
N=414\end{array}$ & $\begin{array}{l}\text { MVC BID + } \\
\text { OBT } \\
N=426\end{array}$ \\
\hline $\begin{array}{l}\text { Continuing to OBT alone of open-label } \\
\text { WVC BID + OBT }\end{array}$ & $n=111$ & $n=239$ & $n=259$ \\
\hline \multicolumn{4}{|l|}{$\begin{array}{l}\text { Patients with HIV-1 RNA } \leq 400 \text { opies/mL, } \\
\left.n(\%)^{+}\right)^{+}\end{array}$} \\
\hline Week 48 & $47(22)$ & $214(52)$ & $240(56)$ \\
\hline Week \$6 & $14(7)$ & $190(46)$ & $212(50)$ \\
\hline \multicolumn{4}{|l|}{$\begin{array}{l}\text { Patients with HIV-1 RNA <50 copiesimL } \\
\left.\pi(\% *)^{\dagger}\right)\end{array}$} \\
\hline Week 48 & $35(17)$ & $179(43)$ & $195(46)$ \\
\hline Week \$6 & $12(6)$ & $159(38)$ & $171(40)$ \\
\hline \multicolumn{4}{|l|}{$\begin{array}{l}\text { Wean change from } \mathrm{BL}^{ \pm} \text {in } \mathrm{CD} 4+\text { cell count, } \\
\text { cellsimm }\end{array}$} \\
\hline $\begin{array}{l}\text { Week } 48^{x} \\
\text { Week } \$ 6^{s}\end{array}$ & $\begin{array}{c}+61 \\
+154(n=15)\end{array}$ & $\begin{array}{c}+116 \\
+169(n=215)\end{array}$ & $\begin{array}{c}+124 \\
+187(n=227)\end{array}$ \\
\hline \multicolumn{4}{|l|}{ Stucly discontinuation due to adverse } \\
\hline $\begin{array}{l}\text { From BL to Week } 48 \\
\text { From Week } 48 \text { to Week } 96\end{array}$ & $\begin{array}{l}11(5) \\
10(5)\end{array}$ & $\begin{array}{c}20(5) \\
3(1)\end{array}$ & $\begin{array}{l}19(4) \\
2(<1)\end{array}$ \\
\hline \multicolumn{4}{|l|}{$\begin{array}{l}\text { Stuch discontinuation due to loss of } \\
\text { efficacy. } n: \% \text {. }\end{array}$} \\
\hline From EL to Week 48 & $113(54)$ & $93(22)$ & $97(23)$ \\
\hline From Week 48 to Week 56 & $46(22)$ & $8(2)$ & $9(2)$ \\
\hline $\begin{array}{l}\text { Wecian duration of stucly treatment } \\
\text { exposure, years }\end{array}$ & 0.7 & 2.4 & 2.5 \\
\hline $\begin{array}{l}\text { Patients with serious aclverse events } \\
\text { (SAEs) } n(\%) \text { (from BL to Week } \$ 8 \text { ) }\end{array}$ & $21(10)$ & $53(13)$ & $65(15)$ \\
\hline $\begin{array}{l}\text { Patients with Category C (ADS-defining) } \\
\text { event, } n\left(\%^{*}\right) \text { (from BL to Wweek 96) }\end{array}$ & $11(10)$ & $16(7)$ & $18(7)$ \\
\hline $\begin{array}{l}\text { Patients with malignancies, } n(\% *) \text { (from BL } \\
\text { to Week } 96)\end{array}$ & $7(3)$ & $17(4)$ & $17(4)$ \\
\hline $\begin{array}{l}\text { \% of total number initielly randomized, } \mathrm{N} \\
\text { Discontinuations/missing values classified a } \\
\text { Mean of all pre-dose assessments } \\
\text { Last-cbservation-carried-Iorward approach } \\
\text { Includes only those patierts with a value at } \\
\text { nissing values not imputed }\end{array}$ & Veek $\$ 6$ ti & $\begin{array}{l}\text { g values } \\
\text { it ishown ir }\end{array}$ & 17 \\
\hline
\end{tabular}

Figure I

\section{References}

I. Hardy WD, et al:: Efficacy and safety of maraviroc plus optimized background therapy in treatment-experienced patients infected with CCR5-tropic HIV-I: 48-week combined analysis of the MOTIVATE studies. I5th CROI 2008. Poster 792.

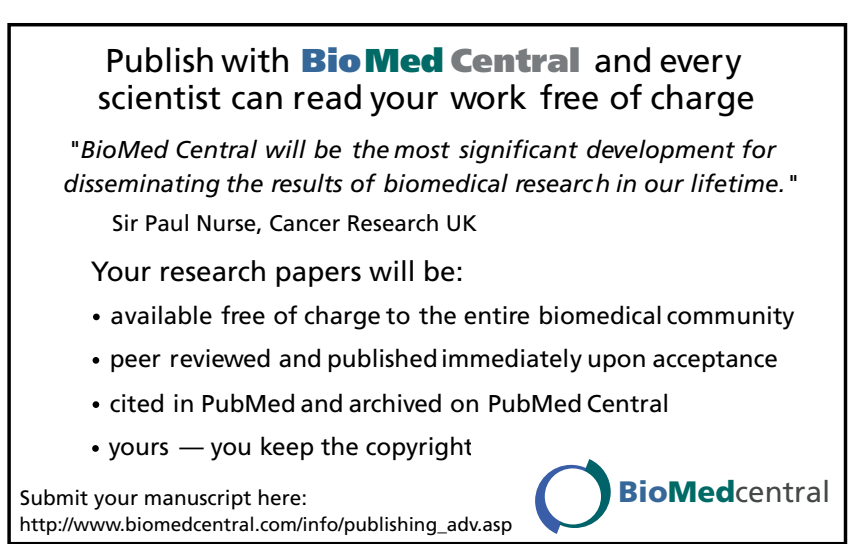

